\title{
Profitability Analysis of Small Scale Fishery Enterprise in Nigeria
}

\author{
Oni Timothy Olukunle ${ }^{1}$ \\ ${ }^{1}$ Economic Policy Research Department, Nigerian Institute of Social and Economic Research, Ibadan, Nigeria \\ Correspondence: Oni Timothy Olukunle, Economic Policy Research Department, Nigerian Institute of Social \\ and Economic Research (NISER), PMB 5 U.I.P.O. Oyo Road, Ojoo, Ibadan, Oyo State, Nigeria. Tel: \\ 234-803-395-0670. E-mail: onikunle2012@ymail.com; olukunleniser2012@gmail.com
}

Received: December 1, 2016

Accepted: February 5, 2017 Online Published: March 15, 2017

doi:10.5539/jas.v9n3p107

URL: http://dx.doi.org/10.5539/jas.v9n3p107

\begin{abstract}
Segmented markets of sub-optimal size existing in fishery value chain do not ensure sizeable private investment in the different stages of the value chain in Nigeria. Supply-demand gaps are increasingly being filled by imports, thus dampening prospects for increased revenue generation by actors in the chain. Market failures in the fish value chain limited capability and performance of small scale fish enterprises at the various stages of the chain. As such this study is prompted by the need to determine and compare profitability of actors along the fish value chain with the use of survey data collected from fishery farmers, marketers and processors. Budgetary framework was used to estimate cost and returns to actors while regression framework was used to estimate determinants of profit at the small scale farm level. The results showed that lowest level of profitability was associated with the producers of fish at farm level. Across all stages, profitability was affected by changes in the cost of labour more than any other costs. In addition, the results showed that profit level declined by $0.04 \%, 0.51 \%, 0.01 \%$, and $0.13 \%$, respectively, for every one percent increase in the cost of labour, fertilizer and liming, feed and pond construction at the small scale farm level. Findings suggest that emphasis of new agricultural promotion policy should be on strengthening linkage and access of small scale operators in fishery subsector to adequate inputs, information, and innovation at reduced costs so as to drive increased investments and profitability in fishery value chain.
\end{abstract}

Keywords: fish, profit, cost, chain, linkage

\section{Introduction}

A new medium-term agricultural promotion policy (APP) for implementation in Nigeria from 2016 to 2020 has laid emphasis on achievement of food security, import substitution, job creation, and economic diversification. As part of its targets, the policy was designed to integrate agricultural commodity value chains into a broader supply chain of global industry. Also, the policy aimed at generating increased foreign exchange earnings from agricultural exports, doubling household income and growth rate in agriculture through improved agricultural productivity. Agricultural export basket is expected to expand from initial narrow range to include fish, cashew nuts, bananas, avocado and mango. In Nigeria, demand for fish is rising owing to the growing population and the changing feeding habits among the citizens as they move towards healthy living. With its cholesterol-free white meat, fish offers the best nutrition profile for humans. Aquaculture is the only sustainable source of fish and has great potential for growth in Nigeria due mainly to the presence of a wide variety of water sources such as rivers, springs, dams, lakes and the oceans. Nigeria has a land area of $923,768 \mathrm{~km}^{2}$ with a length of coastline of $853 \mathrm{~km}$. It also has a vast network of inland waters like rivers, flood-plains, natural and man-made lakes and reservoirs (Shimang, 2010).

Undoubtedly fish farming provides important services such as supporting nutritional well-being of the population, providing feedstock for the industrial sector, making contributions to rural development, increasing export opportunities, enhancing administration of natural resources and conservation of biological diversity (Dagtekin et al., 2007; FAO, 2016). However, the country spends about 125.38 billion every year on the importation of 1.9 million metric tonnes of fish in order to meet demand for the commodity (Federal Ministry of Agriculture and Rural Development, FMARD, 2016). This amounted to $\$ 700$ million every year in terms of foreign exchange spending on fish only. Demand and supply gaps in food has been persistently negative since 1991 such that a gap of about 2 million metric tonnes of fish has been recorded in 2016 (FMARD, 2016) indicating about 30\% self-sufficiency ratio in fishery subsector. In spite of high growth potential of fishery subsector, it has not been able to meet the demand for fish and fishery products in Nigeria. Also its contribution to Gross Domestic Product 
(GDP) remained abysmally low at $4 \%$. Basic amenities and infrastructures are almost non-existent or in poor condition at fishing, processing and marketing sites. Marketing is mostly local but also takes place in major cities which triggers losses incurred during transit. The losses are being aggravated by armed robbery attacks, and vehicle breakdowns arising from poor road conditions. Productivity has been constrained by decline in ocean catch, decline in aquaculture yields and rising cost of fish feed. Segmented markets of sub-optimal size do not ensure profitability of sizeable private investment in the different stages of the commodity chain. Supply-demand gaps are increasingly being filled by imports; thus dampening the prospects for increased revenue generation, and food security. How will there be increased investment in the communities where the commodity is being produced? How will the economic actors in the sub-sector be empowered to gain direct access to markets and remain in the markets? How can profitability of the commodity be improved so as to encourage private investment in the fishery sub-sector. In order to drive private investment in fishery subsector for enhanced income generation, for employment generation and poverty reduction, it is necessary to enhance profitability through linkage of small entrepreneurs in fishery subsector to output market opportunities.

Repositioning the fishery subsector is important now so as to reduce dependency on fish importation and ensure that supply and demand in the subsector can take place in such a way as to enhance food security and provide optimum benefits to the economic agents in the subsector. Furthermore, establishing greater opportunities for strong market, increased productivity, and continuity of expanded profit are fundamental to curtailing the current dramatic levels of fish imports from across the world. It is on the basis of the targets set for the fishery sub-sector in the new agricultural promotion policy of government as enunciated above that this study was carried out to analyse the profitability of the fishery enterprise at the level of small scale operations at production, processing and marketing stages in the commodity value chain with a view to suggest measures to improve performance of actors and improved investment in the fishery value chain.

The remaining sections of the paper are structured as follows. Following this introductory section is section two which presents theoretical framework and review of literature. Research methodology is presented in Section three. Empirical results are discussed in Section four. Recommendations for improving production and profitability of small scale actors in fishery value chain as well as conclusions are presented in section five.

\section{Theoretical Framework and Review of Literature}

Production function provides a guide to entrepreneurs in making decision with regard to optimal use of scarce resources. It follows from production function that dual approach can be used to explore the relationship between production, cost and profit function. Consequently, it is possible to derive profit and cost function from underlying production function. There is duality between production and profit (cost) function such that the existence of one implies the unique existence of the other. The theoretical framework of this study is therefore underpinned by the theory of cost and production function.

\subsection{Theory of Cost}

In the process of agricultural production as in any other production process, cost is incurred. This is so because resources are scarce, hence they attract price and they have alternative uses. In this study attention is specifically focused on fixed and variable costs. Total cost of production is broadly categorized into fixed and variable cost in the short run. However, in the long-run, all factors of production are variable. Fixed costs are the overhead production costs, which do not vary with the level of production. Examples are salaries of permanent staff, rent on land, and depreciation allowance on fixed assets, such as farm buildings, fence, machinery and equipment. Again, the concept of fixed cost is meaningful only in the short-run. In the long run, every cost becomes variable. Variable Costs are the cost incurred as a result of the use of variable inputs in the production process. Variable costs vary with the level of production. Examples are the wages of unskilled labour, transportation cost, and the cost of feed, fertilizers and liming in fish production process. Total cost is the summation of fixed cost and total variable cost. A mathematical formulation of total cost can be expressed as follows:

$$
\mathrm{TC}=\mathrm{TFC}+\mathrm{TVC}
$$

Where, TC represents total cost, TFC stands for total fixed cost and TVC means total variable cost.

\subsection{Total Revenue}

This is defined as the gross receipt obtained from the sale of total product. If TR represents total revenue, Q quantity produced, and $\mathrm{P}$ the unit output price, then total revenue is,

$$
\mathrm{TR}=\mathrm{QP}
$$

\subsection{Profit}


If a farmer can sell all the output that he or she produces at the going market price, the resulting total revenue (TR) function is a line with a constant positive slope of $\mathrm{P}$. TR $=\mathrm{PQ}$, where, $\mathrm{P}$ is constant market price and $\mathrm{Q}$ is the output. The farmer's profit is equal to total revenue (TR) minus total cost (TC). Profit is mathematically expressed as $\Pi=\mathrm{TR}-\mathrm{TC}$ where $\Pi$ is profit. The greatest or maximum profit will be achieved when the difference between TR and TC is greatest (Debertin, 2012).

\subsection{Factors of Production}

The factors of production in agriculture, like those of other forms of production, are traditionally classified into land, labour, capital and management. The costs of agricultural production include the returns to all factors committed to production, such as the wages of hired labour, rent on land, interest on capital, cost of machine hire and expenses on feed fingerlings, fertilizers and liming in fishery enterprise. Labour is the work done by human being, and not the persons themselves. When a farmer hires a laborer, he is buying only so many hours of work and not the man himself (Debertin, 2012). Agricultural production is a labor-intensive activity in Nigeria. In the light of this, the cost of fish production would be highly sensitive to variations in labour cost across time and space. Labour in agriculture could be categorized into family, communal, and hired labour.

\section{Methodology}

\subsection{Sampling Procedure and Data Collection}

The data used in the study were primary data, obtained mainly from a sample survey conducted in 2015 . The survey followed the fish value chain in which data were collected from farmers, marketers and processors of fish The sampling approach for the study followed a multi-stage technique. The first stage is the purposive selection of a state in each geopolitical zones of Nigeria where fishery production predominates. States were selected to achieve pan-territorial spread and to ensure representation of all the six geo-political zones. As such, Lagos, Anambra, Rivers, Niger, Kano, and Adamawa were purposively selected to capture the six geo-political zones in the country. The second stage was the selection of locations noted for the production of fishery in the selected states while third stage involved the selection of respondents. In terms of sampling size, 100 farmers were randomly selected from each state resulting into a total of 600 farmers. Marketers and processors were identified and selected through their trade association. Number of processors, wholesalers and retailers selected depended on the total available number of actors in each case and the established linkage to the commodity value chain. The profitability indicators computed does not necessarily depend on how numerous the respondents are. One limitation of the study especially at the processing and marketing stage is the limited coverage of the value chain participants that volunteered information for the study. Nonetheless, the nature of the analysis is such that the validity of the results depends more on the accuracy of the data especially the input, output and price data than on large number of respondents. As expected for instance, processors, and wholesalers were few. Where actors at a particular level of the value chain were few efforts were made to cover all that volunteered useful information. Data collection process was done with structured questionnaires. Data collected from relevant actors at every level in the fish value chain included socioeconomic characteristics of respondents, size of operations, farm size, costs of equipment for production, processing, fixed assets, revenues, labour (family and hired), input and output prices, and wage rate.

\subsection{Method of Data Analysis}

For the purpose of achieving the stated objective of the study, budgetary analysis was applied. In addition, regression analysis was used to estimate the factors that significantly determine profitability at the production stage. Budgetary analysis encompasses the analysis of cost components such as fixed cost and variable cost of various inputs. Production income, which is the total income or total revenue (TI) in this case, is the monetary value of the output obtained by the actors in the fish value chain. It is expressed as TI $=\mathrm{PQ}$, where $\mathrm{P}$ is the price per unit and $\mathrm{Q}$ is the quantity of output. Production costs, also the total costs in this case, refer to the total expenditure or expenses incurred during a given period on a specified enterprise by the firm. It includes rent on land, pond construction cost, and cost of fingerlings, feed cost, cost of veterinary and drugs, as well as transportation cost amongst others. Depreciation, which is a cost on fixed assets consumed during a given period, was estimated using the straight line method. The common fixed assets used by small-scale fish farmers include water pump and fishing equipment. The components of the enterprise budget are expressed as follows.

$$
\begin{gathered}
\mathrm{TI}=\mathrm{GR}=\mathrm{Q} \times \mathrm{P} \\
\mathrm{TC}=\mathrm{TVC}+\mathrm{TFC} \\
\mathrm{GM}=\mathrm{TI}-\mathrm{TVC} \\
\pi=\mathrm{NP}=\mathrm{GM}-\mathrm{TFC}
\end{gathered}
$$




$$
\begin{gathered}
\text { GRR }=\text { GM/TVC } \\
\mathrm{NRR}=\mathrm{NP} / \mathrm{TC}
\end{gathered}
$$

Where,

$\mathrm{TI}=$ Total income in Naira, GR $=$ Gross revenue in Naira, $\mathrm{Q}=$ Quantity of fish in $\mathrm{Kg}, \mathrm{P}=$ Price per $\mathrm{Kg}, \mathrm{TC}=$ Total cost in Naira, TVC $=$ Total variable cost in Naira, $\mathrm{TFC}=$ Total fixed cost in Naira, GM $=$ Gross margin in Naira, $\mathrm{NP}=\pi=$ Net profit in Naira, GRR $=$ Gross rate of return in ratio and NRR $=$ Net rate of return in ratio.

Profit could either be negative or positive. A positive profit refers to the excess of income over cost of all factors used to produce the output. Negative profit (usually referred to as loss) results when revenue falls short of costs of factors used to produce the output. An investment is profitable if its net rate of return is greater than 1 . Regression analysis was used to determine the relationship between dependent variable, which is Net profit at the farm gate level and cost of inputs used as independent variables. It involves using regression concepts like coefficient of determination $\left(\mathrm{R}^{2}\right)$ to indicate the percentage of dependent variables explained by independent variables and also helps to know if there is a significant relationship between the variables involved. Ordinary Least Squares (OLS) method of regression was chosen over all other econometric techniques because the parameter estimates obtained by OLS have some optimal properties such as unbiasedness, consistency and sufficiency. It also has a simple computation procedure and data requirements are not excessive. The mechanics of OLS are also simple to understand. Following from the theoretical framework, the model for the regression was specified thus:

\subsection{Specification of Empirical Model}

$Y_{i}=f\left(X_{i}\right)$, where, $Y_{i}=$ Net Profit at the farm level, $X_{i}=$ Factors influencing the level of Profit in fish farming.

The model could be written in explicit form as:

$$
Y_{i}=\beta_{o}+\beta_{1} X_{1}+\beta_{2} X_{2}+\beta_{3} X_{3}+\beta_{4} X_{4}+\beta_{5} X_{5}+\beta_{6} X_{6}+\beta_{7} X_{7}+\beta_{8} X_{8}+\beta_{9} X_{9}+\mu
$$

Where,

$Y_{i}=$ Amount of Profit realized by fish farmer; $\beta_{0}, \beta_{1}, \ldots \beta_{9}=$ Parameters; $X_{1}=$ Age of respondent (years); $X_{2}=$ Family size; $X_{3}=$ Years of experience (years); $X_{4}=$ Number of fingerlings that make it to maturity; $X_{5}=$

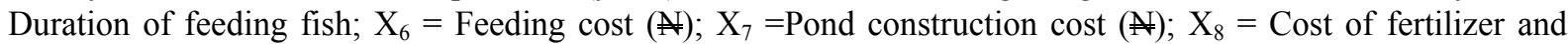
liming; $X_{9}=$ Cost of labour $(\AA) ; \mu$ error term.

The model specified above was analysed for the actors at the farm level using different functional forms of the regression model (linear, semi-log, and double-log) to determine the effects of explanatory variables on amount of profit realized by the farmer. The best functional form was chosen based on the adjusted $\mathrm{R}^{2}$ value and the number of significant variables. The double-log function was eventually considered as being best suited to capture the effects of the independent variables on the profit of the fish farmer which is the dependent variable. The reason for choosing the double-log function was based on the highest adjusted $\mathrm{R}^{2}$ compare to others and most of the variables were significant at the appropriate level and they possessed the appropriate sign on each of the co-efficient.

\section{Empirical Results and Discussion}

\subsection{Financial Costs and Profitability Indicators}

The analysis focuses on key indicators of profitability in the fishery value chain which includes production, processing, and trading. Fish production at farm stage is concerned with primary production of aquaculture fishery and ends with the sale of matured fish by the farmers to processors and marketers at the farm gate. These transactions may occur literally at the farm gate or at some other point where the farmer hands over ownership of the product to the next value chain participant who may be a processor and or marketer. Depending on the farmer, some type of primary processing may take place at the farm level. Magnitude and structure of financial costs are important in the analysis because the magnitude of cost will affect the performance of the actors at various stages of the chain while the structure will provide the opportunity to identify specific cost items that can be targeted by actors in a bid to improve the performance of the chain. As expected, the type and composition of costs vary from one stage to another. At the production stage, labour cost is the highest; representing $37 \%$ of the total cost. This is followed by purchased inputs such as foundation stock, manure and feed representing $35 \%$. The combination of transportation, storage and marketing constitutes $20 \%$ of the total cost. The remaining group of variables which constitutes depreciation and interest charges accounts for about $8 \%$ of the total cost (See Figure 1). One can infer from Figure 1 that the farmers will need to focus on reducing the cost of labour, the cost of feed and foundation stock as well as transportation and marketing cost if the total cost of operation were to be reduced 
substantially. The high cost of feed observed in the total cost of production at the farm level is consistent with the findings of previous authors such as Ugwumba (2011), Pius and Victor (2014) who concluded that the cost of feed represented the lion share of total production cost of aquaculture in Nigeria.

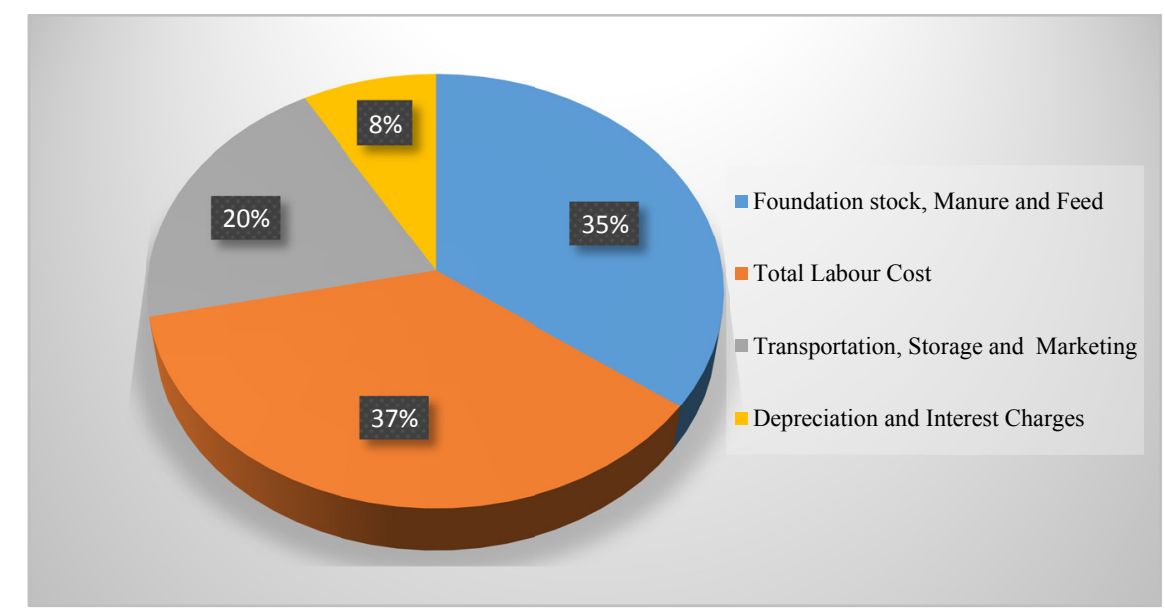

Figure 1. Build-up of farmers financial costs (\% total cost)

Source: Author's computation.

Breakdown of rural roads and poor transportation could limit fish farmer to operating at small scale rather than expanding his farm. This is because small scale farmers are risk averse and they have the tendency to avoid wastages at harvesting since linkage to markets could be disrupted. The parlous state of rural roads and rural bridges in Nigeria could hinder movement of farm inputs to the farm and farm output to the markets which in turn could result into operating at low capacity by the actors at the farm level. Also, the collapse of the infrastructure could heighten the cost of movement of farm inputs such as fish foundation stock, and feed from the production firms to farmsteads. This could eventually lead to shutting down of fishery enterprise and shifting of resources to other competing enterprises.

For frozen fish, at the processing stage, the operational cost, excluding raw fish, are dominated by hired labour, which constitutes $68 \%$ of the cost while energy, machine repairs and maintenance accounted for $24 \%$ of the cost. Other cost items are depreciation of equipment which represented $6 \%$ while taxes, levies, interest charges and communication represents about $2 \%$ of the cost (See Figure 2). The substantial component of the cost of energy could be attributed to the instability in electricity supply in the country and the associated high cost of alternative source of energy which is generating set. The cost of energy may be heightened by recent increase in the price of fuel in the country. The dominance of labour cost at the processing stage was in agreement with the findings of Abolagba and Nuntah (2011) who found that processing of fish in some selected states of Nigeria was lucrative but are constrained by high cost of labour and transportation resulting into low standard of living of an average processor in the states covered by the study. Hence they concluded that government should engage in the rehabilitation of the access routes leading to the processing communities, so as to improve transportation system and facilitate transportation of processed fish. 


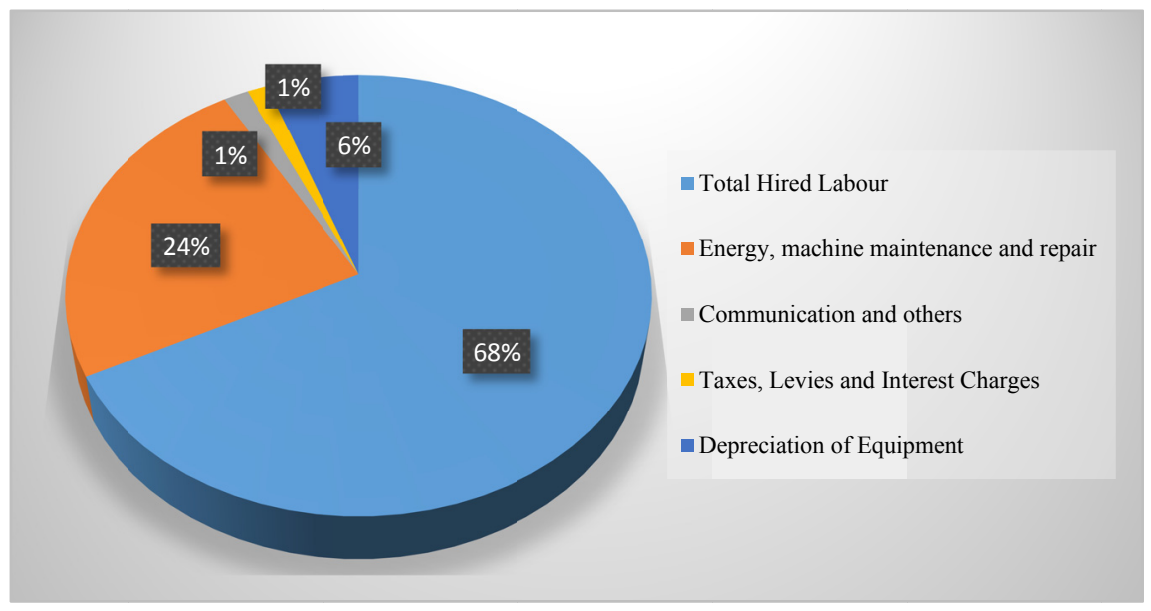

Figure 2. Build-up of procesing cost (frozen fish) in \% of total cost (excluding products purchased)

Source: Author's computation.

The structure of cost for processing raw fish into dry fish appears to be similar to that of processing raw fish into frozen fish in which the operational cost, excluding raw fish is dominated by hired labour which constitutes $57 \%$ of the cost while energy, equipment repairs and maintenance constitutes $28 \%$ as shown by Figure 3 . At the logistics stage(domestic distribution), the relevant cost items in order of importance are total labour cost which constitutes $68 \%$ of the cost (Figure 4).The combination of transportation to delivery point as well as marketing which accounted for $29 \%$ of total cost. The dominance of labour and transportation cost at the domestic distribution stage could be attributed to the poor transportation system in the rural sector of the Nigeria economy. These findings conform to those of Abolagba and Nuntah (2011) that was earlier mentioned. The result implies that transport improvement would increase accessibility and enlarge markets for labour and other inputs among various market actors such as input suppliers, labour and customers. This could lead to expansion and integration of markets and could in turn open new channels for product and labour markets.

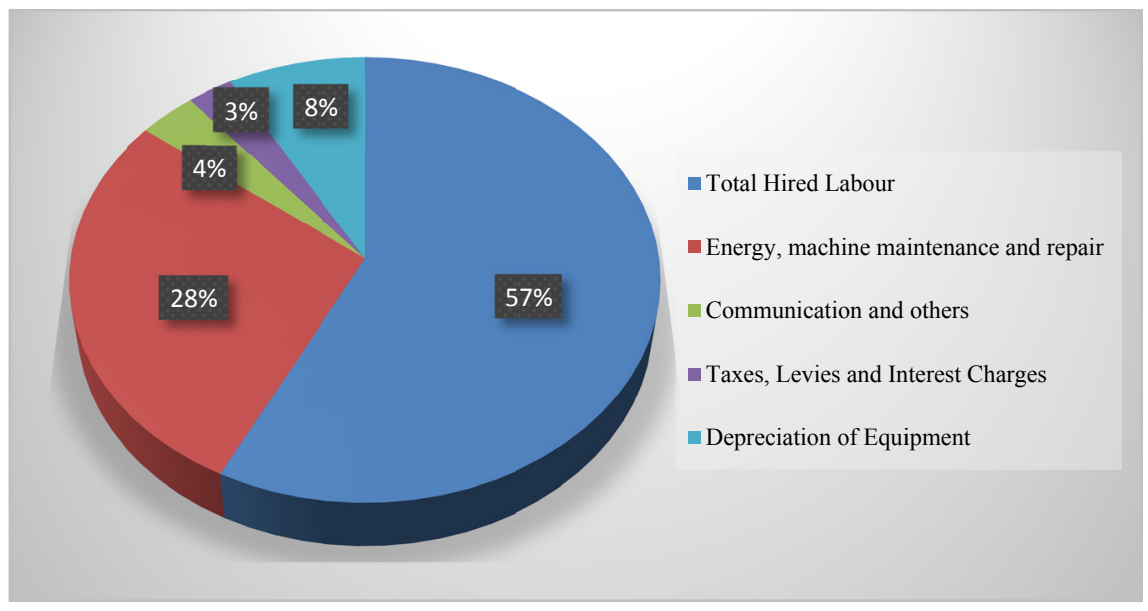

Figure 3. Build-up of processing cost (dry fish) in \% of total cost (excluding products purchased)

Source: Author's computation.

As transport system improves the transportation costs will be reduced and creates potential for market expansion and integration. This will empower fish farmers who will be able to draw labor from broader areas and with wider ranges of attributes. This will in-turn improve labour supply and reduce its costs. Similar effects will occur when transport improvements open up new farms for more production activities. 


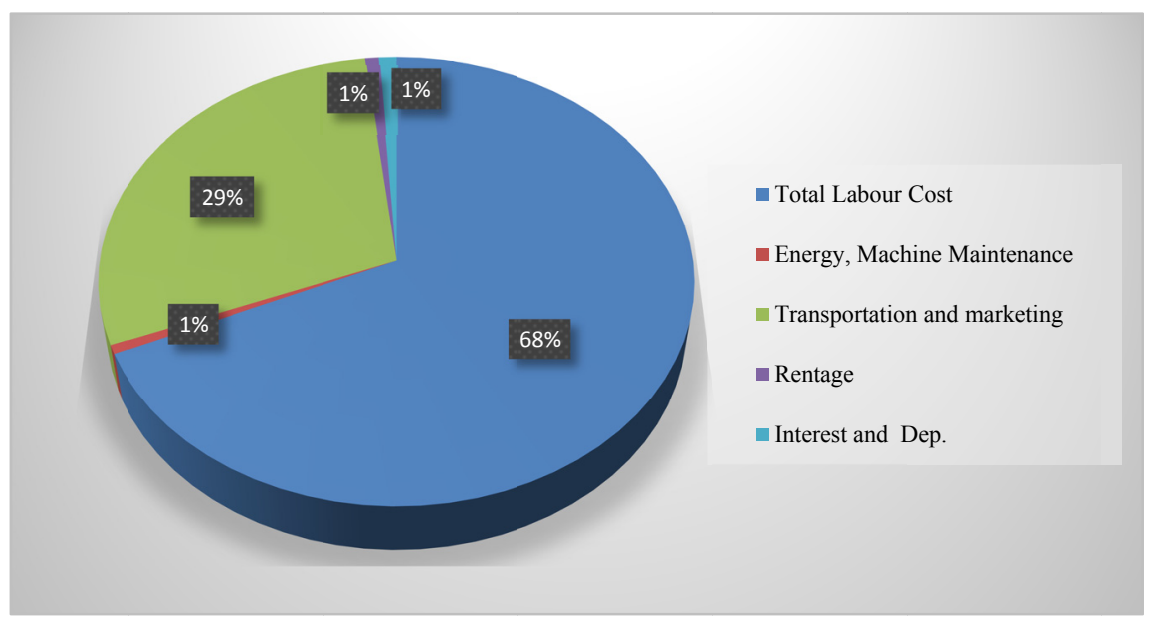

Figure 4. Build-up of trading cost in \% of total cost excluding products purchased (dry fish)

Source: Author's computation.

\subsection{Profitability Indicators}

The analysis of profitability indicates that each stage of the fishery value chain was profitable. As shown in Table 1 , profitability was at a very moderate level across all stages. At the production stage, gross margin per metric tonne of fish was $\$ 149,481$ while net profit was $\$ 141,101$ whereas at the processing stage, the gross margin per tonne was $\$ 312,270$, while net profit was $\$ 309,331$ for frozen fish. At the processing stage for dry fish, the gross margin was $\$ 286,399$ while net profit was $\$ 277,044$. In the case of producers, gross rate of return stood at $161 \%$ while net rate of return was $139 \%$. The net rate of return to processors was very close to that of the producers. At the logistic stage, the gross margin per metric tonne of dry fish was $\$ 183,551$ while the net profit was $\$ 155,463$. As shown in Table 1, the gross rate of return associated with the logistic stage involving delivery of the dry fish to the final destination in the domestic market stood at $61 \%$ while the net rate of return stood at $47 \%$. The results revealed that the lowest level of profitability was associated with the producers of fish at farm level while the highest profitability level was associated with the processors of fish.

Table 1. Indicators of fishery enterprise profitability in Nigeria (Per MT)

\begin{tabular}{lllll}
\hline Indicators & $\begin{array}{l}\text { Farm Gate Product } \\
\text { Aquaculture } \\
\text { (Value in Naira) }\end{array}$ & $\begin{array}{l}\text { Processed Products } \\
\text { Frozen Fish } \\
\text { (Value in Naira) }\end{array}$ & $\begin{array}{l}\text { Processed Products } \\
\text { Dry Fish } \\
\text { (Value in Naira) }\end{array}$ & $\begin{array}{l}\text { Traded Commodity } \\
\text { Dry Fish } \\
\text { (Value in Naira) }\end{array}$ \\
\hline TVC & $92,786.09$ & $287,729.62$ & $178,600.81$ & $300,197.13$ \\
TFC & $8,379.69$ & $2,939.82$ & $9,354.88$ & $28,089.39$ \\
TC & $101,165.78$ & $290,669.44$ & $187,955.69$ & $328,286.52$ \\
G.R & $242,266.67$ & $600,000.00$ & $465,000.00$ & $483,750.00$ \\
G.M. & $149,480.57$ & $312,270.38$ & $286,399.19$ & $183,552.87$ \\
NP & $141,100.89$ & $309,330.56$ & $277,044.31$ & $155,463.48$ \\
GRR & 1.61 & 1.09 & 1.60 & 0.61 \\
NRR & 1.39 & 1.06 & 1.47 & 0.47 \\
\hline
\end{tabular}

Source: Authors' computation based on Field Survey Data, 2015.

\subsection{Determinants of Profitability at the Farm Level}

The double-log form of the specified empirical model was selected as lead equation on the basis of Adjusted $\mathrm{R}^{2}$, sign and sizes of the regression parameters. Estimated parameters and the related statistical tests for determinants of aquaculture profitability at the farm level is presented in Table 2 . As shown by the Table, the result is a good 
fit of the data as Adjusted $\mathrm{R}^{2}$ indicates that the independent variables explain $51 \%$ of variation in net profit that accrued to an average farmer. The coefficients of the variables in the results give the partial effect of the variable on profit level at the farm gate. The regression coefficients have expected signs. The results in the table showed that five variables are significant determinants of the amount of profit that accrued to the farmer. These are cost of labour, cost of fertilizer, cost of feed, pond construction cost and years of experience. The estimated coefficient of labour cost is negative as expected and significant at $10 \%$. The negative sign shows increasing labour cost will lead to a decline in profit level. The magnitude of the coefficient, 0.041 shows that a one percent increase in cost of labour will bring about $0.04 \%$ decline in profit level. This is consistent with the findings of Pius and Victor 2014. The coefficient of cost of fertilizer and liming is negative and significant at 5\% indicating that increase in cost of fertilizer and liming will induce a decrease in profit level and vice versa. The magnitude of the coefficient, 0.51 shows that a one percent increase in cost of fertilizer and liming will lead to $0.51 \%$ decrease in profit and vice versa. To increase the profit level at the farm level, it will require a reduction in the cost of fertilizer and liming. The coefficient of cost of feed is negative $(-0.01)$ and significant at $5 \%$. The negative sign shows increasing feed cost will lead to a decline in profit level. The magnitude of the coefficient, 0.01 shows that a one percent increase in cost of feed will bring about $0.01 \%$ decline in profit level. The findings of Ugwumba (2011), Pius and Victor 2014 showed that the cost of fish feeds accounted for major component of the total cost of production. On a similar note, the result of this study revealed that cost of fish feed ranked as a major share of the total cost of production. By implication, fish feed is a major ingredient for aquaculture fish farming.

Table 2. Determinants of profitability at farm level (Dependent variable: Amount of net profit at farm level in natural logarithm)

\begin{tabular}{lllll}
\hline Independent Variables in Natural Logarithm. & Coefficient & Standard errors & t-statistics & Significance \\
\hline Age of farmers $\left(\mathrm{X}_{1}\right)$ & 0.002 & 0.120 & 0.017 & 0.421 \\
Years of experience & 0.101 & 0.046 & 2.196 & $0.052^{* *}$ \\
number of fingerlings that make it to maturity & 0.001 & 0.024 & 0.042 & 0.210 \\
Duration for feeding fish & 0.021 & 0.085 & 0.247 & 0.123 \\
Cost of Feed & -0.010 & -0.0004 & 2.5010 & $0.051^{* *}$ \\
Pond construction cost & -0.132 & -0.021 & -6.28 & $0.001^{* * *}$ \\
Cost of Fertilizer and Liming & -0.512 & -0.210 & -2.43 & $0.049^{* *}$ \\
Cost of labour & -0.041 & -0.015 & -2.6 & $0.082^{*}$ \\
\hline
\end{tabular}

Note. $*$ means variables significant at $10 \% ; * *$ means variables significant at $5 \%$; $* *$ means variables significant at $1 \% . \mathrm{R}^{2}=0.57$; Adjusted $\mathrm{R}^{2}=0.51$.

Source: Author's computation based on Field Survey Data, 2015.

The regression coefficient for pond construction cost is negatively related to profit level. A one percent change in pond construction cost will contract amount of profit by $0.13 \%$. This is highly significant at $1 \%$ level. The regression coefficient for years of experience gives a positive relationship with amount of profit realized by the farmer. A one percent change in years of experience will improve the profit level by $0.1 \%$. This variable is significant at 5\% level. This is supported by Pius and Victor (2014) who found that the effect of farming experience on aquaculture output and profit realized is positive. This implies that an increase in the experience of the farmers in aquaculture farming leads to an increase in profit realized by fish farmers.

\section{Policy Implications and Conclusion}

The results showed labour as a crucial component of total cost which featured prominently across all stages in the fishery value chain. Across the various stages, profitability in the fishery value chain was affected by changes in the cost of labour. In addition to cost of labour, costs of feed, fertilizer, liming, pond construction and years of experience were also significant determinants of profit that accrued to the average actor at the farm level. The finding imply policy emphasis will be on providing a high technology that will enhance labour efficiency across the various stages in the fishery value chain. Moreover, physical infrastructure and enhancing access to adequate inputs, information on innovation and agricultural services should be given adequate attention by the government. This is very significant factor that would attract private investors and hence expand the scale of operation at 
various stages of the value chain. The new agricultural promotion policy must focus on improved access by the economic agents to productivity enhancement variables such as improved access to fertilizer, feed, pond-water, improved knowledge and innovation. This would improve significantly the productivity of actors particularly the farmers which in turn will lead to improved profitability at the farm level where the profit level remained the lowest. Policy focus must also include disseminating information designed to help fish farmers make best choices with respect to input costs.

\section{References}

Abolagba, O. J., \& Nuntah, J. N. (2011). Survey on Cured Fish Processing, Packaging, Distribution and Marketing in Edo and Delta States. International Research Journal of Biotechnology, 2(5). Retrieved from http://www.interesjournals.org

Dagtekin, M., Ak, O., \& Emeksiz, F. (2007). Socio-economic analysis and marketing patterns of the fish farming industry in Trabzon, Turkey. Retrieved September, 2015, from http://www.fao.org/docrep/012/i1373e92.pdf

Debertin, D. L. (2012). Agricultural Production Economics (2nd ed.). Macmillan Publishing Company, NJ, USA. Retrieved from http://uknowledge.uky.edu/agecon_textbooks/1

Federal Ministry of Agriculture and Rural Development (FMARD). (2016). The Agriculture Promotion Policy (2016-2020). Building on the Successes of the ATA, Closing Key Gaps. Policy and Strategy Document.

Federal Ministry of Agriculture and Rural Development (FMARD). (2013). Mid-Term Report on Agricultural Transformation Agenda. FMARD, Abuja, Nigeria.

Food and Agriculture Organization (FAO). (1983a). Inland Aquaculture in Nigeria: Improving Fingerling Supply and Fish Nutrition for Smallholder Farmers.

Food and Agriculture Organization (FAO). (1983b). Fish Feed and feeding in developing countries (UNDP/FAO/DCP/REP/83/18, pp. 1-17).

Food and Agriculture Organization (FAO). (2016a). Global Aquaculture Production Statistics database updated to 2013. Retrieved from http://www.fao.org/3/a-14899e.pdf

Food and Agriculture Organization (FAO). (2016a). The State of World Fisheries and Aquaculture. Food and Agriculture Organization of the United Nations, Rome.

Food and Agriculture Organization (FAO). (2016b). FAO Fisheries and Aquaculture Fishery and aquaculture country profiles. The Federal Republic of Nigeria. Retrieved from http://www.fao.org/fishery/facp/NGA/en

NBS. (2016). Nigerian Gross Domestic Report. National Bureau of Statistics. Retrieved from http://www.nigerianstat.gov.ng

Olayide, S. O., \& Heady, E. O. (1982). Introduction to Agricultural Production Economics. Ibadan University Press, University of Ibadan, Nigeria.

Olayide, S. O., Eweka, J. A., \& Bello-Osagie, V. E. (1980). Nigerian Small Farmers: Problems and Prospects in Integrated Rural Development (pp. 2-15). Centre for Agricultural and Rural Development, University of Ibadan, Nigeria.

Pius, C. I., \& Victor Azuka, C.-O. (2014). Determinants of Output and Profitability of Aquaculture Fish Farming in Burutu and Warri South West Local Government Areas of Delta State, Nigeria. Journal of Biology, Agriculture and Healthcare, 4(28). Retrieved from http://www.iiiste.org

Shimang, G. N. (2010). Fisheries Development in Nigeria, Problems and Prospects. A presentation by the Federal Director of Fisheries in the Federal Ministry of Agriculture and Rural Development on Homestead Fish Farming Training in the Federal Ministry of Agriculture and Rural Development, Abuja, Nigeria.

Ugwumba, A. A., \& Ugwumba, A. O. (2003). Aquaculture options and the future of fish supply in Nigeria. The Zoologist, 2, 96-122.

Ugwumba, C. O. A. (2011). Technical Efficiency and Profitability of Catfish Production in Anambra State, Nigeria (Unpublished PhD Thesis). Department of Agricultural Economics, Delta State University, Abraka, Nigeria.

Ugwumba, O. A. (2016). From the Surface Water to the Deep Sea Bed: Fish, the Real Masters of the Aquaworld. An Inaugural Lecture Delivered at the University of Ibadan, Nigeria. 


\section{Copyrights}

Copyright for this article is retained by the author(s), with first publication rights granted to the journal.

This is an open-access article distributed under the terms and conditions of the Creative Commons Attribution license (http://creativecommons.org/licenses/by/4.0/). 